International Journal of Linguistics, Literature and Translation

ISSN: 2617-0299 (Online); ISSN: 2708-0099 (Print)

DOI: 10.32996/ijltt

Journal Homepage: www.al-kindipublisher.com/index.php/ijltt

\title{
Disc Jockeys' Profile and Oral Performances in the Selected English Vowel Sounds: An Attempt on Relatedness
}

\author{
Lylee Norah M. AbdelGafur 8 (D) \\ Assistant Professor IV, English Department, Mindanao State University-Main Campus, Marawi City, Philippines \\ $\square$ Corresponding Author: Lylee Norah M. AbdelGafur, E-mail: abdelgafur29@gmail.com
}

ARTICLE INFORMATION

Received: July 08, 2021

Accepted: August 14, 2021

Volume: 4

Issue: 8

DOI: $10.32996 /$ ijllt.2021.4.8.4

\section{KEYWORDS}

Pronunciation, Vowel Sound

Production, Disc Jockey,

Communication, Oral

Communication

\section{ABSTRACT}

Pronunciation is a key element of the learning of oral skills in a second language. The role it plays in an English language program varies and the amount of time and effort devoted to it seems to depend to a large degree on the linguistic models and environment (Willing, 1988). The study examined the accuracy in the production of the selected English vowel sounds among the pioneering Disc Jockeys of Cool FM, Marawi City, in the year 2004. Moreover, it attempted to find the relatedness in the respondents' oral performances and in their educational status, length of work experience as a DJ, and exposure to the language outside being a DJ. Three selected faculty members from the English Department of CSSH were consulted to evaluate the oral performances of the respondents. Results showed that high educational status did not affect the respondents' performances in vowel sound production. Respondents with short work experience as DJs could perform better on the oral test. Respondents who had exposures to the English language outside being a DJ performed better on the oral test. Furthermore, teachers and foreigners were cited as good linguistic models that were described as highly influential in the performances of the respondents.

\section{Introduction}

Part of the need to communicate and be understood is the precision of sound production. Discrimination between vowels or sounds largely affects listening or reception - thus, affecting the process of communication. (Gilakjani, 2012) emphasized that learners need to achieve understandable pronunciation as it is one of the basic requirements of learners' competence. Good pronunciation facilitates learning, while bad pronunciation could interfere with language learning. Some words may be common to people, but they would also mean a different thing when pronounced differently. Some examples are beach - bitch / $\mathrm{i} / \mathrm{I} /$, meat - met $/ i /-/ \epsilon /$, sheet - shit $/ i / / /$. When these words were mispronounced esspecially, the vowel sounds may create confusion for the listeners.

As explained, "consonant sounds in English are found in the beginning or end of a syllable core. The sound within the syllable that resonate and can be lengthened or shortened is the vowel sound. In fact, a vowel can even constitute a syllable or a word, as in 'eye'" Vowels enable us to speak the language easily. We can articulate words clearly only if they contain vowel sounds. Consider saying the following words: Thr $v$ sprm mprtns. Jst tr sng nthng $n \mathrm{Nglsh}$ wht thm. (They are of supreme importanc. Just try saying anything without them) (Brown, 2000).

In the study, the researcher examined the accuracy in the production of the selected English vowel sounds among Disc Jockeys in Cool FM, Marawi City on the year 2004. Moreover, the study attempted to find the relatedness in the respondents' oral performances and in their educational status, length of work experience as a DJ, and exposure to the language outside being a DJ.

\section{K C AL-KINDI CENTER $\mathbf{R}$ D FOR RESEARCH AND DEVELOPMENT} Your gateway to world-class research

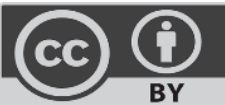

Published by Al-Kindi Center for Research and Development, London, United Kingdom. Copyright (c) the author(s). This open access article is distributed under a Creative Commons Attribution (CC-BY) 4.0 license 
The researcher aimed to reflect the significance of the study to show how pronunciation is a key element of the learning of oral skills in a second language. The role it plays seems to depend to a large degree on the linguistic models and environment (Willing, 1988).

\subsection{Statement of the Problem}

The study sought to answer the following questions: (1) What was the profile of the DJ respondents in terms of educational status, length of work experience as a DJ, and exposure to the language (outside the station), considering the frequency they used the language, period they learned to use it; and avenue where they learned it. (2) What were the respondents' performances in the vowel sound production? (3) Is there relatedness between the respondents' performances of the given vowel sounds, and their educational status, length of work experience as a DJ, and exposure to the language (outside the station), considering the frequency they used the language, period they learned to use it, and avenue where they learned it?

\subsection{Scope and Limitations of the Study}

The study was an attempt to describe the relatedness of the oral performances of the respondents and their profiles mentioned in the statement of the problem and the respondents' exposure to the language. Disc Jockeys (DJs) of 95.5 COOL FM in Marawi City, were selected as the respondents because they had an English-Only-Policy (EOP) during the time of the study, AY 20042005. There were only EIGHT (8) respondents, as were the active DJs at that time.

The test given had only covered selected English words with vowel sounds. The study could not use a correlational design due to lack of respondents. Due to limited time and number of DJs, the study's findings may not be generalized in other given conditions and populations, nor are they applicable to other DJs in another setting.

\subsection{Definition of Terms}

The following terms are defined conceptually (taken from Dictionary.com, LLC (2021) and other sources) and operationally for the readers to understand fully the meaning of the terms used in the study.

Accuracy. It refers to the condition or quality of being true, correct, or exact; freedom from error or defect; precision or exactness; correctness. In the study, it refers to how close perfection is one able to produce the vowel sounds.

Disc-Jockey (DJ). It is a person who conducts a radio broadcast consisting of recorded music, informal talk, commercial announcements, etc. In the study, DJs from 95.5 COOL FM are the respondents.

Enunciation. It refers to utterance or pronunciation. In the study, it is the utterance or mode of the utterance of vocal sounds.

IPA. It refers to International Phonetic Alphabet. The study refers to the IPA symbols used in the transcription of the words containing vowel sound production of the respondents.

Language Exposure. According to a well-known study of second language exposure, the quality of the language environment that the student is surrounded by is crucial to success in learning a new language. (Crocker, 2019). The study refers to the DJs' exposure to the English vowel sounds in the following settings: home, school, friends, work experience as a DJ, and media forms.

Linguistic Models. Linguistic models deal with statements as they are used to express meanings. (Nikolai Mansourov, 2011)

Performance. The execution or accomplishment of work, acts, feats, etc. In the study, it refers to the scores of the respondents in the vowel sound production.

Pronunciation. An accepted standard of the sound and stress patterns of a syllable, word, phrase, etc. In the study, it refers to the way the respondents produced the vowel sounds.

Radio. An apparatus for receiving or transmitting radio broadcasts. The study refers to the FM Station, specifically $95.5 \mathrm{COOL}$ FM located in Marawi City, Philippines.

Relatedness. Associated; connected. In the study, it refers to the relationship of the scores of the respondents with their profiles. 


\section{Literature Review}

This section presents concepts, views, and reviews of related literature and studies on phonology, pronunciation, and the factors affecting second language acquisition and learning.

Phonology is the study of the patterns of sounds in a language and across languages. More formally, phonology is the study of the categorical organization of speech sounds in languages; how speech sounds are organized in mind and used to convey meaning. In the study, the vowel sounds of English are used in the oral test of the respondents.

Phonology can be related to many linguistic disciplines, including psycholinguistics, cognitive science, sociolinguistics, and language acquisition. Principles of phonology can also be applied to treatments of speech pathologies and innovations in technology. In terms of speech recognition, systems can be designed to translate spoken data into text. In this way, computers process language like our brains do. The same processes that occur in the mind of a human when producing and receiving language occur in machines. One example of machines decoding language is the popular intelligence system Siri (School of English, 2021)

Similarly, there is a need to review concepts of pronunciation. Pronunciation is defined as the production of English sounds. Pronunciation is learnt by repeating sounds and correcting them when produced inaccurately (Cook, 1996). When learners start learning pronunciation, they make new habits and overcome the difficulties resulting from the first language. According to Yates (2002 as cited in Pourhosein Gilakjani, 2016), pronunciation is the production of sounds used to make meaning.

Pronunciation is the production of a sound system that doesn't interfere with communication either from the speakers' or the listeners' viewpoint (Paulston, 1976). Pronunciation is the way of uttering a word in an accepted manner (Otlowski, 1998). Furthermore, (Richards, 2002) defined pronunciation as the method of producing certain sounds (Gilakjani P. , 2016)

Specifically, vowel, in human speech, sound in which the flow of air from the lungs passes through the mouth, which functions as a resonance chamber, with minimal obstruction and without audible friction; e.g., the $i$ in "fit," and the $a$ in "pack." Although usually produced with vibrating vocal cords, vowels may be pronounced without such vibration, resulting in a voiceless, or whispered sound. From the viewpoint of articulatory phonetics, vowels are classified according to the position of the tongue and lips and, sometimes, according to whether or not the air is released through the nose. (Encyclopaedia Britannica, 2021)

Sometimes people assume that there are five vowel sounds in English: A, E, I, O and U. However, this is a misconception. These are vowel letters, not vowel sounds. Each vowel letter can represent more than one sound. For example, the letter a can represent /æ/ as in hat, /ey/ as in hate, /a/ as in car, or / $/$ / as in care. Also, each vowel sound can be represented in more than one way in spelling: The sound /iy/ can be written as ee in seem, as ea in seal, as ie in piece, as ei in receipt, as ey in key, as i...e in the machine, and perhaps more. There's certainly not a one-to-one correspondence between letters and sounds, and English has many more vowel sounds than vowel letters. For most speakers of American English, there are 14 vowel sounds, or 15 if we include the vowel-like sound in words like bird and her (Yoshida, n.d.)

In the study, the chosen respondents were Disc Jockeys. Disc-jockey, also spelt disk jockey, person who conducts a program of recorded music on radio, on television, or at discotheques or other dance halls. Disc-jockey programs became the economic base of many radio stations in the United States after World War II. The format generally involves one person, the disc-jockey, introducing and playing music and chatting informally and usually extemporaneously in the intervals. (Encylopaedia Britannica, 2021)

The Critical Period Hypothesis claims that an optimal period for language acquisition exists and that this period ends at puberty (Abello-Contese, 2009) as cited in (Koay, 2021). Studies that adhere to this hypothesis typically focus on pronunciation and grammar, as (DeKeyser, 2009) summarizes.

Although it is generally agreed that children are better at learning a language than people past a certain age, opinions of this hypothesis vary. A limited view of the critical period hypothesis holds that learner's biological age determines the ability to learn a language. While this might be partially true, it is important also to consider social, affective, educational, and experiential aspects that intersect with age (Abello-Contesse, 2009).

Modelling of communication is always associated with the pragmatic aspect as the inevitable look at communication from the point of view of its main participant - the person. Knowledge of the language system (e.g., language rules) is only one of the 
prerequisites for the success of linguistic communication; the other prerequisite is a sufficiently auto-mated strategies and mechanisms of production and processing of expressions, constructed in accordance with this system (Dem'janenkov, 1984) as cited in (Zh.N, 2018).

The concepts of "pragmatic context" and "pragmatic understanding" introduced by T.A. van Deijk are quite interesting. In his opinion, pragmatic understanding is a kind of sequence of processes, the content of which is attributing the statements of the participants of communication special conventional nature of illocutionary force (Dejk, 2000). Information can come from different sources and through different channels. First, it is the grammatical structure of the utterance, which is defined by rules. Second, paralinguistic characteristics (e.g., gestures, facial expressions, rate of speech, stress, intonation); communication is often successful because of the verbal and non-verbal forms can be used simultaneously during the primary message. Thirdly, it is knowledge and opinions about the talking, the features of this and previous communicative situation, knowledge of a general nature (for example, the conventional rules about the interaction), and general knowledge about the world. The success of communication is most likely when the parties communicate in a specific context have the same set of pragmatic presumptions, exerting a decisive influence on the wording of the statements, and, consequently, on their interpretation.

Krashen's second language acquisition theory consists of five main hypotheses the Acquisition-Learning hypothesis, the Monitor hypothesis, the Input hypothesis, and the Affective Filter hypothesis, the Natural Order hypothesis are explained (Schütz, 1998).

The Acquisition-Learning distinction is the most fundamental of the five hypotheses in Krashen's theory and the most widely known among linguists and language teachers. According to Krashen there are two independent systems of foreign language performance: 'the acquired system' and 'the learned system'. The 'acquired system' or 'acquisition' is the product of a subconscious process very similar to the process children undergo when they acquire their first language. It requires meaningful interaction in the target language - natural communication - in which speakers are concentrated not in the form of their utterances, but in the communicative act (Krashen, 1987).

The Monitor hypothesis explains the relationship between acquisition and learning and defines the influence of the latter on the former. The monitoring function is the practical result of the learned grammar. According to Krashen, the acquisition system is the utterance initiator, while the learning system performs the role of the 'monitor' or the 'editor'. The 'monitor' acts in a planning, editing and correcting function when three specific conditions are met:

The Input hypothesis is Krashen's attempt to explain how the learner acquires a second language - how second language acquisition takes place. The Input hypothesis is only concerned with 'acquisition', not 'learning'. According to this hypothesis, the learner improves and progresses along with the 'natural order' when he/she receives second language 'input' that is one step beyond his/her current stage of linguistic competence.

The Affective Filter hypothesis embodies Krashen's view that several 'affective variables' play a facilitative but non-causal, role in second language acquisition. These variables include motivation, self-confidence, anxiety, and personality traits. Krashen claims that learners with high motivation, self-confidence, a good self-image, low anxiety, and extroversion are better equipped for success in second language acquisition. Low motivation, low self-esteem, anxiety, introversion, and inhibition can raise the affective filter and form a 'mental block' that prevents comprehensible input from being used for acquisition. In other words, when the filter is 'up' it impedes language acquisition. On the other hand, positive affect is necessary but not sufficient on its own, for acquisition to take place.

Finally, the less important Natural Order hypothesis is based on research findings ((Dulay \& Burt, 1974) cited in Krashen (1987) which suggested that the acquisition of grammatical structures follows a 'natural order' which is predictable. For a given language, some grammatical structures tend to be acquired early, while others are late. This order seemed to be independent of the learners' age, L1 background, and exposure conditions. Although the agreement between individual acquirers was not always $100 \%$ in the studies, statistically significant similarities reinforced the existence of a Natural Order language acquisition. Krashen, however, points out that the implication of the natural order hypothesis is not that a language program syllabus should be based on the order found in the studies. In fact, he rejects grammatical sequencing when the goal is language acquisition. 


\section{Methodology}

The study uses Descriptive research design instead of correlational due to limited number of respondents. The study was conducted in Marawi City, wherever the respondent was to be found. There were eight (8) respondents, with 3 females and 5 males, who were working as Disc Jockeys in 95.5 COOL FM during the time of the study. The instruments used were questionnaires (self-made for the profiles) and cassette recorder for the vowel sound production. The oral test was a 1-minute impromptu delivery, using the respondent's usual DJ talk to open a show, introduce a song and close a program. Selected words with vowel sounds were taken to evaluate three selected faculty members from the English Department of CSSH. The results were analyzed and interpreted through simple frequency-percentage count and evaluated further to find relatedness between the respondents' oral performances and their profiles.

\section{Results and Discussion}

Based on the data gathered and their analyses, the findings were drawn to answer the research questions. For problem questions number 1 in terms of the profiles of the study, data showed that all of the respondents were students, where five of them were fourth-year students. Three of the respondents had worked as Disc Jockeys for three years. The data showed that all of the respondents have exposure to the English language at home, school, and with friends. Most of them learned the language during their elementary grades. Moreover, the respondents considered their teachers and foreigners as their linguistic models. As mentioned, modelling of communication is always associated with the pragmatic aspect as the inevitable look at communication from the point of view of its main participant - the person. Knowledge of the language system (e.g., language rules) is only one of the prerequisites for the success of linguistic communication; the other prerequisite is a sufficiently automated strategies and mechanisms of production and processing of ex-pressions, constructed in accordance with this system (Dem'janenkov, 1984) as cited in (Zh.N, 2018).

For problem question number 2 on the oral performances of the respondents, Table 1 illustrates the summary of the results of the oral performances of the respondents. Table 1 presents the summary of scores of the respondents in the vowel sound production. The first column shows the profile of the respondents in terms of educational status. The second column indicates the frequency distribution of educational status. While the third column has scores of the respondents in terms of percentage. As shown, two of the respondents have the perfect score of 100 percent from the vowel sound production, while the lowest score is 86.66 percent. The Critical Period Hypothesis claims that an optimal period for language acquisition exists and that this period ends at puberty (Abello-Contese, 2009) as cited in (Koay, 2021). Studies that adhere to this hypothesis typically focus on pronunciation and grammar, as (DeKeyser, 2009) summarizes.

Table 1. Summary of Scores of the Respondents in the Vowel Sound Production

\begin{tabular}{|c|c|c|}
\hline \multicolumn{1}{|c|}{ Respondent } & Frequency & Percentage \\
\hline $\begin{array}{c}\text { High School } \\
\text { 4th year }\end{array}$ & 1 & 91.03 \\
\hline College & 1 & 100 \\
1st Year & 1 & 100 \\
$2^{\text {nd Year }}$ & 5 & 95.53 \\
4th year & & 93.33 \\
DJ1 & & 97.73 \\
DJ2 & & 91.11 \\
DJ3 & & 86.66 \\
DJ4 & & $\mathbf{1 0 0}$ \\
\hline DJ5 & $\mathbf{8}$ & \\
\hline
\end{tabular}

For problem question number 3 , in terms of finding relatedness between the oral performances of the respondents and their profiles, the results showed that their educational status did not necessarily affect their performance in the sound production. Those who scored the highest had good linguistic models in their schooling, as shown in the following table 2.

The Input hypothesis is Krashen's attempt to explain how the learner acquires a second language - how second language acquisition takes place. The Input hypothesis is only concerned with 'acquisition', not 'learning'. According to this hypothesis, the learner improves and progresses along with the 'natural order' when he/she receives second language 'input' that is one step beyond his/her current stage of linguistic competence. 
Table 2. Educational Status of the Respondents

\begin{tabular}{|c|c|c|}
\hline Respondent & Frequency & Percent Scores \\
\hline $\begin{array}{l}\text { High School (4th year) } \\
\text { College }\end{array}$ & 1 & 93.33 \\
\hline 1st $Y r$ & 1 & 100 \\
\hline $2^{\text {nd }} Y r$ & 1 & 100 \\
\hline 4th $Y r$ & 5 & 93.29 \\
\hline TOTAL & 8 & 100 \\
\hline
\end{tabular}

In terms of length of work experience as Disc Jockeys, there were four who worked for 1-6 months, one for 6-12 months, and three for 1-3 years. As shown in the following table, the highest score is 97.73 , the respondent who worked for 6-12 months only as compared to those who worked for 1-3 years, as shown in Table 3.

Krashen (1987) said that the acquisition of grammatical structures follows a 'natural order' which is predictable. For a given language, some grammatical structures tend to be acquired early, while others are late. This order seemed to be independent of the learners' age, L1 background, and exposure conditions. Although the agreement between individual acquirers was not always $100 \%$ in the studies, statistically significant similarities reinforced the existence of a Natural Order language acquisition. Krashen, however points out that the implication of the natural order hypothesis is not that a language program syllabus should be based on the order found in the studies. In fact, he rejects grammatical sequencing when the goal is language acquisition.

Table 3. Respondents' Length of Work Expérience as a DJ

\begin{tabular}{|c|c|c|}
\hline Length of Work Expérience as DJ & Frequency & Percent Scores \\
\hline \multicolumn{3}{|l|}{ Months } \\
\hline 1-6 months & 4 & 97.21 \\
\hline 6-12 months & 1 & 97.73 \\
\hline Years & & \\
\hline $1-3$ years & 3 & 91.06 \\
\hline TOTAL & 8 & 100 \\
\hline
\end{tabular}

In terms of exposure to the language and frequency of the use of the language in categories as : home, school, and with friends, results showed that the majority of the respondents 'seldom' spoke the language at home, 'often' in school, and with friends. Therefore, the respondents have exposure and frequent us of the language is in school and with friends as shown in Table 4.

The Input hypothesis is Krashen's attempt to explain how the learner acquires a second language - how second language acquisition takes place. The Input hypothesis is only concerned with 'acquisition', not 'learning'. According to this hypothesis, the learner improves and progresses along with the 'natural order' when he/she receives second language 'input' that is one step beyond his/her current stage of linguistic competence.

Table 4. Frequency of the Use of Language

\begin{tabular}{|c|c|}
\hline Frequency Use of Language & Frequency \\
\hline \multicolumn{2}{|l|}{ Home } \\
\hline Always & 1 \\
\hline Seldom & 3 \\
\hline Often & 2 \\
\hline Never & 2 \\
\hline \multicolumn{2}{|l|}{ School } \\
\hline Always & 2 \\
\hline Seldom & 3 \\
\hline Often & 3 \\
\hline Never & 0 \\
\hline \multicolumn{2}{|l|}{ With Friends } \\
\hline Always & 0 \\
\hline Seldom & 4 \\
\hline
\end{tabular}




\begin{tabular}{|c|c|}
\hline Often & 4 \\
Never & 0 \\
\hline TOTAL & $\mathbf{8}$ \\
\hline
\end{tabular}

As for the period, the respondents have learned the language as in preschool, elementary, high school and college years, the majority of them learned during their elementary years, as shown in Table 5. Although it is generally agreed that children are better at learning a language than people past a certain age, opinions of this hypothesis vary. A limited view of the critical period hypothesis holds that learner's biological age determines the ability to learn a language. While this might be partially true, it is important to also consider social, affective, educational, and experiential aspects that intersect with age (Abello-Contesse, 2009).

Table 5. Period of Learning the language

\begin{tabular}{|l|c|}
\hline \multicolumn{1}{|c|}{ Period } & Frequency \\
\hline Preschool & 1 \\
Elemetary & 6 \\
High School & 1 \\
College & 0 \\
\hline TOTAL & $\mathbf{8}$ \\
\hline
\end{tabular}

Whereas for the avenues where the respondents learned the language as: family, teaches, movies, cartoons, foreigners, and radio, results showed that 'teachers' and 'foreigner' were the primary sources of the respondents in learning the language. Family, cartoons, and movies ranked next as shown in Table 6.

The Acquisition-Learning distinction is the most fundamental of the five hypotheses in Krashen's theory and the most widely known among linguists and language teachers. According to Krashen there are two independent systems of foreign language performance: 'the acquired system' and 'the learned system'. The 'acquired system' or 'acquisition' is the product of a subconscious process very similar to children's process when they acquire their first language. It requires meaningful interaction in the target language - natural communication - in which speakers are concentrated not in the form of their utterances but in the communicative act (Krashen, 1987).

Table 6. Avenues of Respondents in Learning the Language

\begin{tabular}{|l|c|}
\hline \multicolumn{1}{|c|}{ Avenues } & Frequency \\
\hline Family & 4 \\
Teachers & 1 \\
Classmates & 0 \\
Friends & 0 \\
Movies & 8 \\
Cartoons & 3 \\
Foreigners & 1 \\
Radio & 1 \\
\hline
\end{tabular}

\section{Conclusion}

The study attempted to find relatedness in the vowels sound production of Disc Jockeys and their profiles. Based on the study's findings, data showed that the highest educuational status might not affect the respondents' performance in vowel sound production. Respondents with short work experience as DJ could perform better than those with longer work experience. Results also showed that school was the primary source of the language learning of the respondents. Those who said they had good linguistic models performed better in the oral test, even if they had learned to use the language in their high school years. Teachers and foreigners were found highly influential in the performances of the respondents.

Based on the findings of the study, it showed promising results for finding significant relationships. Due to time and respondent constraints, the researcher could not use statistical instruments to show significant relationships. Hence, the researcher highly recommends a further study to find correlational relationships between the variables given and their oral performance in other aspects of language and consider more respondents. 
Funding: This research received no external funding.

Acknowledgements: The researcher would like to acknowledge the invaluable contributions of the following people in the completion of the study: the undergraduate Thesis Adviser Dr. Erlinda De Luna, the respondents of the study, her family, and the Almighty Allah.

Conflicts of Interest: The authors declare no conflict of interest.

\section{References}

[1] Dulay \& Burt. (1974). Natural Sequences in child Second Language Acquisition. Journal of Research in Language Studies

[2] Abello-Contese, C. (2009). Age and the critical period hypothesis. ELT Journal, 170-172.

[3] Brown, D. H. (2000). Principles of language learning \& teaching. (4th ed.). New York: Longman. Retrieved from https://bit.ly/3zXLaQ8

[4] Cook, V. (1996). Second Language Learning and Language Teaching. Arnold.

[5] Crocker, M. (2019, May 20). Retrieved from https://www.teflcourse.net/blog/why-exposure-is-important-when-learning-asecond-language-ittt-tefl-blog/

[6] Dejk, V. T. (2000). Language, Cognition, Communication. 308.

[7] DeKeyser, R. M. (2009). The robustness of critical period effects in second language acquisition. Studies in Second Language Acquisition , 499-533.

[8] Dem'janenkov. (1984). On Formalization of the Pragmatic Properties of Language. 197-222.

[9] Dictionary.com, LLC. (2021). Retrieved from https://www.dictionary.com/browse/accuracy

[10] Encyclopaedia Britannica. (2021, July 25). Retrieved from https://bit.ly/3j9HKTt

[11] Encylopaedia Britannica. (2021). Retrieved from https://bit.ly/3lh7U9u

[12] Gilakjani, A. P. (2012, March). Retrieved from https://bit.ly/3jbJgEy

[13] Gilakjani, A. P. (2016, November 18). Retrieved from https://bit.ly/37eFyo1

[14] Gilakjani, P. (2016). What Factors Influence the English Pronunciation of EFL Learners? .

[15] Koay, D. J. (2021, April 24). EduMaxi. Retrieved from https://bit.ly/3lmmWL9

[16] Krashen, S. D. (1987). Principles and Practice in Second Language Acquisition. Prentice-Hall International.

[17] Nikolai Mansourov, D. C. (2011). ScienceDirect. Retrieved from https://www.sciencedirect.com/topics/computer-science/linguistic-model

[18] Otlowski, M. (1998). Pronunciation: What Are the Expectations? The Internet TESL Journal.

[19] Paulston, C. B. (1976). Teaching English as a Second Language, Techniques and Procedures. Cambridge: Winthrop Publisher, Inc.

[20] Richards, J. C. (2002). Longman Dictionary of Language Teaching and Applied Linguistics. 3rded. UK: Pearson Eduction Limited.

[21] School of English. (2021, July ). Retrieved from https://bit.ly/3rlnCvC

[22] Schütz, R. E. (1998, April). Retrieved from https://bit.ly/2Vo843S

[23] Willing, K. (1988). Learning styles in adult migrant education. Australia: NCRC Research Series.

[24] Yoshida, M. (n.d.). Retrieved July 25, 2021, from https://bit.ly/2WBlusN

[25] Zh.N, S. (2018, November 2). Retrieved from https://bit.ly/3lefF01 